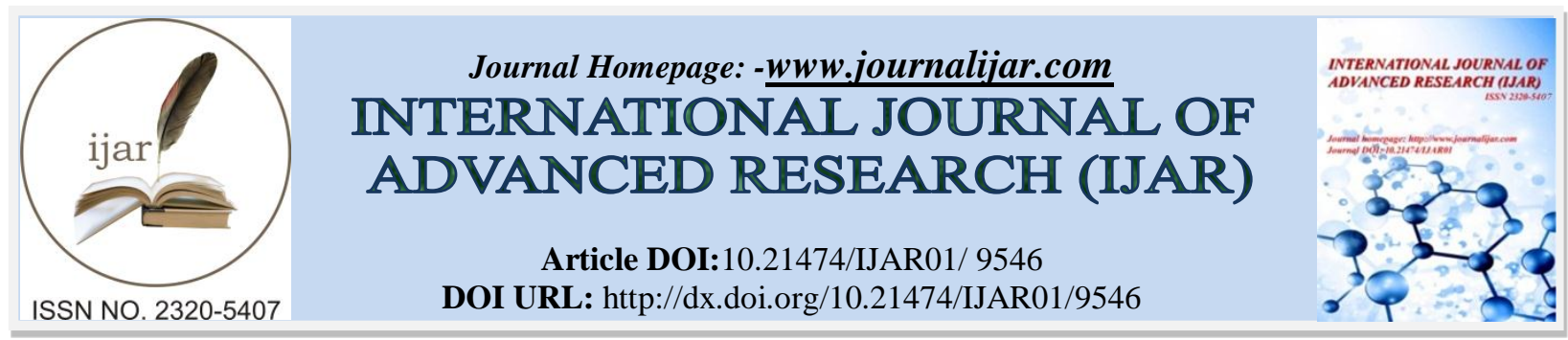

RESEARCH ARTICLE

\title{
CULTIVATION STRATEGY OF MARITIME RESISTENCE IN NATUNA DISTRICT TO SUPPORT NATIONAL RESISTENCE.
}

\author{
Cecep hidayat $^{1}$, Z. Fanani ${ }^{2}$, Setyo widagdo ${ }^{2}$ and Fadillah putra ${ }^{2}$. \\ 1. Postgraduate student of brawijaya university. \\ 2. Postgraduate lecturer of brawijaya university.
}

\section{Manuscript Info}

Manuscript History

Received: 08 June 2019

Final Accepted: 10 July 2019

Published: August 2019

\begin{abstract}
The purposes of this study are 1) to analyze the current condition of Maritime Resilience in Natuna Regency, 2) to analyze Maritime Security policies in Natuna District, 3). To analyze what factors support and hinder the implementation of maritime resilience policies in Natuna Regency, and 4) to find the right concepts and strategies to strengthen maritime resilience in Natuna Regency. This research was carried out at Lanal Ranai and Indonesian Navy Station, Lamper Strait Dock, Raden Sjajad Airport, Alif Stone (Tourism place), Regent Office, Great Ranai Mosque, Public Port, Police Station in Natuna and Fisheries in East Bunguran, Natuna. While the research was conducted on September 2018 to March 2019. This study used a qualitative descriptive method with observation and deepening of material for quite a long time. The results of this study are known how the conditions of maritime resilience and policies related to maritime resilience in Natuna Regency and the factors that support and hinder the implementation of policies in Natuna Regency. Then managed to find a new model or concept, which named hybrid Maritime Resilience with a "PASTI MAJU" strategy. So that it can be used to strengthen maritime resilience in Natuna Regency.
\end{abstract}

\section{Introduction:-}

Indonesia is one of the largest archipelagic states in Asia and the second state which has 17,504 with information on 16,056 islands in the world that have been standardized and submitted to the United Nations. Indonesia is a country that has an area of 6.4 million $\mathrm{km}^{2}$ of water, with a coastline of 108,000 km, and an exclusive Economic Zone (EEZ) as wide as 200 miles in the United Nations Convention on the Law of the Sea 1982 (UNCLOS '82) with an area of 3 million $\mathrm{km}^{2}$ (Pushidrosal, 2018). History has explained that in the fact that the Indonesian people are a nation that has identity as a maritime nation, but that perspective has faded and even disappeared due to the entry of the era of colonialism in the archipelago. Indonesia has experienced its glory as a maritime country by utilizing the sea as one of its supporting milestones. With its sea power, Archipelago kingdoms such as the Srivijaya kingdom and the Majapahit kingdom had experienced their golden era and became a great kingdom in their time.

Corresponding Author:-Cecep hidayat.

Address:-Postgraduate student of brawijaya university. 
This identity is being rebuilt by the current government by implementing Nawacita programs. Nawacita is a great concept made by the government of the Indonesian President Joko Widodo and Vice President Jusuf Kalla to advance Indonesia as a sovereign, independent and personality maritime nation. The concept of Nawacita which was proclaimed by the Government of Indonesia constitutes 9 (nine) priority agendas in the direction of development policies used in running the current government, in accordance with the mandate of the constitution and contains the ideals and goals of the nation as in Pancasila and the 1945 Constitution. the vision of the World Maritime Axis which aims to accelerate the development and enforcement of Indonesian sovereignty in the maritime field.

There are many islands that are the outermost parts of the NKRI, one of which is the Natuna Islands. Researchers have their own interest in the region because they see enormous potential and a very strategic position. The area of Natuna Regency is $224,684.59 \mathrm{~km}^{2}$ with a land area of $2,000.85 \mathrm{~km}^{2}$ and an ocean area of $222,683.74 \mathrm{~km}^{2}$. Natuna Regency consists of islands, there are 154 islands in the Regency, with 27 islands (17.53\%) inhabited and 127 islands $(82.44 \%)$ uninhabited. Of all existing sub-districts, Serasan sub-district has the highest number of uninhabited islands, 30 islands (23.62\% of the total uninhabited islands). Natuna Regency currently faces a big threat, namely the high number of violations in the sea caused by illegal fishing activities by KIA who are escorted and protected by their country's Coast Guard. In order to strengthen its maritime resilience, Natuna Regency must improve its deficiencies in infrastructure, facilities, facilities, conditions of human resources, defense and security and the synergy between the Regency Government and the private sector, the government and law enforcement officials. But Natuna Regency also has great potential as a force that can support the strengthening of their maritime resilience, such as the potential of fisheries and marine, tourism, oil and gas and the environment.

\section{Research purposes:-}

Based on the above background, the research objectives are as follows;

1. Analyzing the condition of Maritime Resilience in the current Natuna Regency

2. Analyzing Maritime Resilience policies in Natuna Regency

3. Analyzing the factors that support and hinder the implementation of maritime resilience policies in Natuna Regency

4. Finding the right concepts and strategies to strengthen maritime resilience in Natuna Regency

\section{Research Methods:-}

Research Time and Location: -

This research was carried out at Lanal Ranai and Indonesian Navy Station, Lampah Strait Dock, Raden Sjajad Airport, Alif Stone (Tourism Place), Regent Office, Great Ranai Mosque, Public Port, Police station in Natuna and Fisheries in East Bunguran, Natuna. These places are considered to have a very important role in obtaining important data and information where the research is carried out. While the research was conducted in September 2018 until March 2019.

\section{Research methods: -}

This study uses a qualitative descriptive method by understanding social reality, that is seeing the world as it is and not the world it should be. In addition, qualitative research is scientific research that aims to understand a phenomenon in a social context naturally by putting forward the process of in-depth communication between researchers and the phenomenon under study.

\section{Data source:-}

Respondents in this study were 8 key informants consisting of SKK Oil and gas Business Support Deputy, Lanal Ranai Commander, Head of Natuna District Transportation Agency, 2 staff of the Ranai Transportation Office, 1 of Lubuk Lumbang fisherman chairman, 2 fishermen. Then 5 additional informants from the Navy, they are 1 legal officer, 1 intelligence officer who served in Lanal Ranai, 1 medical person who served in Natuna integration hospital, 2 officers who served on the KRI and had carried out security operations sea in the North Natuna Sea.

\section{Data Retrieval Techniques: -}

The technique used to collect the data needed is: primary data obtained through in-depth interviews with predetermined respondents and several respondents who were randomly selected. Secondary data is obtained through documentation from relevant agencies and from various other relevant reference materials. The researcher will also make direct observations in the field to obtain secondary data and other facts that can support it. 


\section{Data analysis technique: -}

Data obtained in this qualitative study was carried out by means of 1) in-depth interviews to obtain information (data) from respondents by asking face-to-face questions (Mashud and Musta'in, 2005), 2) Observation participates directly and intensively to get accurate information and data in connection with the activities studied. With observation, it can be observed the activities of people, physical characteristics, social situations, and what happens in certain places (Spradley 1980), and 3) Study of documentation.

\section{Research Result And Discussion:- Data Analysis:- Current Maritime Resilience Conditions in Natuna Regency: -}

U.S. The Department of Homeland Security Center of Excellence (2016) in the 7th Annual Maritime Resilience Symposium entitled "Integrating Maritime and Coastal Resilience" explained that resilience is the capacity or ability of a system, both physical and human, to prepare for disturbances, absorb or resist stress due to disturbances and recovering from the impact at the right time and adapting to intrusive ways in the future (Holling, 2001).

When interpreting the system, the most relevant thing is the system that is owned and used in the area (both policies and rules). Then the physical can be interpreted as the condition of infrastructure, facilities, infrastructure and potential of natural and artificial possessions. Then humans are the condition and ability of humans to manage the potential that exists in the region, both natural and artificial potential. Because the research carried out aims to improve maritime resilience, then Natuna Regency should have infrastructure, facilities to support strong maritime sector, large maritime sector potential, good human resource capacity in managing maritime potential and a government system that supports improved infrastructure conditions, existing infrastructure and maritime potential.

To identify and analyze maritime resilience conditions in Natuna Regency today, SWOT activities are used. Freddy Rangkuti (1997) in SWOT Analysis: Technique of dissecting a Business Case issued by PT. Gramedia Main Library, explained that the SWOT analysis is one of the analysis tools for solving problems faced by various organizations that want an assessment of the desired plan by comparing internal factors which are grouped as Strength and Weakness and external factors grouped as Opportunity and Threat. This needs to be done to analyze and validate what factors are both internal and external that can influence the concepts and strategies that must be implemented so that the results are more optimal in order to strengthen maritime resilience in Natuna Regency

\section{Strength \\ Defense And Security Potential}

In order to strengthen maritime resilience in Natuna Regency, the aspects of defense and security are one of the keys to achieve strong maritime resilience. The presence of military forces in Natuna Regency greatly affected the existing conditions of resilience. So that it is expected to be able to prevent and overcome various threats and disturbances that arise. The seriousness of the Indonesian Government to strengthen defense and security aspects in the Natuna region is realized by the establishment of the Natuna TNI (STT) Integrated Unit inaugurated by the TNI Commander, Marshal Hadi Tjahyanto, SIP in December 2018. With the development of the Natuna TNI Integrated Unit it will strengthen the Defense aspect and Security in the Natuna Islands, especially in the context of facing violations of sovereignty and law and can provide deterrence effects for regional countries. Although Natuna has been formed a new Marine Composite Battalion currently which serves to strengthen defense and security, but the function of the Natuna STT has not been able to strengthen the maritime resilience that exists in Natuna Regency. This is because the quality and quantity of maritime radars is still minimal, the number and pattern of titles of Navy warships, Bakamla ships and KKP vessels are still insufficient and have not been managed effectively and efficiently so that they have not been able to prevent early and overcome acts of illegal fishing committed by foreign fishermen, especially Vietnamese fishermen who carry out activities in the Indonesian Exclusive Economic Zone (ZEEI) and the Indonesian Continental Shelf in the North Natuna Sea

\section{Potential of Fisheries and Marine Affairs}

The potential of fisheries owned by Natuna region is very large, it can be seen from the total potential in 2016 amounted 1,143,340 tons. But in 2017 it decreased where the total potential was only 767,155 tons. This shows that the potential of fisheries in Natuna Regency is very large, but due to the still rampant acts of illegal fishing in Natuna waters, thus affecting the income of the fisheries sector in Natuna. This potential is not only used to capture fisheries, but in 2017 has been developed by the Central Government through an integrated fisheries dock construction program and its facilities in the Strait, cage rocks, fish seeds, marine mud seeds and the assistance of 
inkamina ships. So that changing the pattern of fish searches from dead fish fishermen to live fish fishermen by maintaining and cultivating sonok fish and kerapu fish species at cages.

\section{Tourism Potential}

In addition to the potential in the field of fisheries, the tourism sector is also a promising and important potential to be developed to attract tourists and open employment opportunities for the Natuna community to increase regional income, economy and community welfare in order to strengthen maritime resilience in Natuna. The natural beauty, contours and authenticity of the beaches in Natuna Regency can be explored into marine tourism sites that can attract domestic and foreign tourists.

\section{Oil and Gas Potential}

The Natuna Islands have a huge source of oil and gas wealth and offshore mining. This is one of the attractions for foreign countries to control the territorial waters of the Natuna Islands. The mineral wealth of the mine is not only on land, but also found under the sea. According to government figures, Natuna has the largest natural gas reserves in the Asia Pacific region, this refers to one of the gas fields located $225 \mathrm{~km}$ north of Natuna. Here natural gas reserves are stored with a volume of 222 Trillions of Cubic Feet (TFC). In addition, hydrocarbon gas that can be mined reaches 46 TFC. Oil and gas originating from weathering fossils of marine animals over millions of years ago contributed around 10.11 percent of the economy of the Riau Islands Province. Income from oil and gas mining in all exploration wells in Natuna is very large.

\section{Environmental Potential}

One of the new potentials that is owned after Natuna is designated as a National Geopark area which aims at conservation, education and the economy. This has been encouraged by the Indonesian Ministry of Foreign Affairs and the Ministry of Maritime Affairs to make the Geopark a UNESCO Global Geopark. This positive signal must be supported by the Natuna Regency Government by continuing to preserve the existing natural and ecosystem conditions. As a Regency that has characteristics that can be said to be unique because it has 154 islands, with 27 islands (17.53 percent) inhabited and 127 islands (82.44 percent) uninhabited, Natuna Regency Government must think about how to maintain the sustainability and ecosystem of the islands uninhabited. Because with the large number of islands that exist, is one of the keys to the creation of an interesting Geopark.

\section{The majority of Natuna Regency's profession is as Fishermen}

Based on data from the Natuna Regency Central Bureau of Statistics in 2017, it is known that there are 20,571 Natuna people whose economies depend on fisheries potential, $97.6 \%$ depend on fishing activities, $1 \%$ related to fish trade, $1.1 \%$ related to fish processing businesses and $0.3 \%$ is related to the fishing boat / fishing boat industry. From these data it is known that the majority of the people of Natuna Regency work as fishermen. This is an opportunity to manage the potential of existing fisheries. The Natuna Regency Government must be able to take advantage of this opportunity by developing policies that can facilitate fishermen to develop.

\section{Weakness}

\section{Defense and security conditions}

With the construction of the Natuna TNI Integrated Unit in Ranai, Natuna Regency, it will strengthen the Defense and Security aspects of the Natuna Islands, especially in order to deal with threats and disturbances by providing deterrence effects on Natuna Waters. But the quantity and quality of personnel, infrastructure, facilities, facilities and information technology must be further improved, by adding a number of things, such:

1. Air radar capability;

2. Capability of maritime surveillance radar;

3. Air base and fighter aircraft

4. Special wharves for warships with tonnages above $2500 \mathrm{GT}$,

5. Depth above 10 meters and can be leaned on by submarines; and

6. Beaching dock for Landing Ship Tank (LST) vessels.

\section{The condition of facilities, infrastructure and facilities is still inadequate Water transportation}

Sea transportation is the main transportation to support maritime activities which are used daily as transportation for the distribution of marine products, agriculture, plantations and other natural products. In addition, transportation is 
also the heart of the activity that takes place because it is used as a primary transportation facility for both subdistricts, villages and provinces by the people in Natuna Regency.

\section{Port / Dock}

The condition of the existing infrastructure and dock facilities in Natuna Regency is about $60 \%-80 \%$. However, there is still one (1) dock that is in a state of severe damage, which named the Navy Marine Island Station dock.

\section{Land transportation}

Based on the data obtained, in March 2018, the road conditions were still inadequate because if there were 2 (two) large trucks or buses that were larger than 2 (two) directions at the same time less safe. So that it can endanger the safety and security of vehicles and traffic jams. The lack of road lighting (PJR) and traffic signs makes the condition of the highway in Natuna Regency still prone to traffic accidents and accidents. Whereas from the vehicle facilities used to support economic activities in Natuna Regency, especially in Bunguran Island, most people use chartered cars, motorbikes, trucks and mini buses as means of transportation between villages or sub-districts whose numbers are very limited and the operating hours are limited to hours certain.

\section{Air Transportation}

Infrastructure, air transportation infrastructure facilities are still not the main choice for the Natuna Regency community because ticket prices that exist today are still relatively expensive, but air transportation still has its own market and segments so it must continue to be improved. Can be said at this time, air transportation is a very promising alternative for the development of potential sectors in Natuna Regency, including the fisheries, tourism also oil and gas sectors. Ranai Airport is a form of synergy between the Natuna Regency Government and the Air Force. Because the building infrastructure was built using the budget of the Natuna Regency Government and runaway was built by the Air Force. Until 2018 there are only 2 (two) flight routes and there are only 3 (three) airlines operating there.

\section{Means of communication and internet networks}

The condition of the internet communication and network facilities in Natuna Regency is currently inadequate. This is proven by the existence of 4 (four) blank spot areas in Natuna Regency. In addition, the internet network is still unstable and often disappears as the reason for communication with the telephone becomes less clear. Then the internet access that is obtained is still not good even though there is already a $3 \mathrm{G}$ network, but when going to send an email it is still difficult. This condition can certainly be an obstacle and obstacle, because to achieve strong maritime resilience, the means of communication and internet networks are one of the determining factors. The development plan made by the Natuna Regency Government should not only be about physical conditions, but also the systems in it. Progress in existing technology must be able to be used to prioritize effectiveness and efficiency.

\section{Human resource capacity is still lacking Education}

Based on data obtained from the Natuna Regency Regional Research and Development Planning Agency (BP3D), up to 2018 SD / MI (Elementary School) conditions that were still good only reached $34.39 \%$ of the 80 schools. Then SMP / MTs (junior high school) that are still good only reach 50\% of the 33 schools. Whereas for SMA / MA and Vocational High School (Senior High School) the conditions of eligibility are still unknown. However, starting in 2018, the number of SMA / MA is only 17 schools, while SMK is only 5 schools. The number of SD / MI and SMP / Mts conditions that are feasible and the number of SMA / MA and SMK in Natuna Regency is still not able to improve the quality of education in the Natuna Regency community.

\section{Health}

The condition of infrastructure, health infrastructure in Natuna Regency is currently considered to be lacking and inadequate. This can be seen based on the results of research obtained from the Natuna Regency Research and Development Planning Agency (BP3D) explaining that in 2017, the number of Puskesmas that have 5 (five) types of health workers is only 8 (eight) health centers and only 6 (six) sub-districts that have at least 1 (one) health center that is certified accreditation. 
Synergy between the Government and the private sector, the community and law enforcement officials in Natuna

In order to achieve strong maritime resilience, the Natuna Regency Government must truly synergize with all the components of defense and security in Natuna Regency, both TNI, POLRI and other agencies to establish good and solid communication and coordination. So that it can be detected early on various problems and obstacles that occur in the field and solutions can be immediately sought.

\section{Opportunities (Opportunity)}

Plans for the development of Natuna Regency by the Central Government, Riau Province and Natuna Regency

The biggest opportunity that exists today is how the Central Government has begun planning Natuna development on a large scale. It is known from the existence of several coordination meetings on the arrangement of spatial and fisheries in Natuna waters. The fisheries sector seems to be the main focus, because until now the potential of fisheries in Natuna has not been explored optimally. The presence of threats and disturbances in the form of illegal fishing is a major factor for local fishermen not having the courage to find fish until the territory of the Continental Shelf and the Indonesian Exclusive Economic Zone. This massive development plan must be fully utilized to improve all existing weaknesses so that the potential of Natuna Regency can be managed optimally. If this can be done, Natuna Regency is ready to face various threats and disturbances.

\section{Program of cooperation with related stakeholders}

Another opportunity that is currently created is the collaboration program with related stakeholders who also manage the potential of Natuna Regency, namely SKK Oil and gas and supported by Medco E \& P Natuna with Premier Oil Natuna Sea BV. The collaboration program that has been running is Corporate Social Responsibility (CSR). With this program the Natuna Regency Government is greatly helped to improve existing infrastructure, facilities and facilities. The results of the development carried out through the CSR program were obtained from the Fact Sheet Development Program for the Upstream Oil and Gas Industry in Natuna Regency in 2018 provided by SKK Oil and gas staff.

\section{Threat}

Nine-dash line claims

This problem arises as a result of China's desire to control all natural resources in the South China Sea. Claims made by China in the South China Sea directly involve several ASEAN countries, namely Vietnam, the Philippines, Malaysia, Brunei and Taiwan, while for Indonesia itself the Chinese team of nine dashed lines in the LCS can indirectly lead to regional conflicts and potential the loss of natural resources for oil and gas in the North Natuna Sea which is included in one of the nine dash lines in China. Actually, Indonesia only has a status as a non-claime state, but in some instances there have also been illegal fishing violations by KIA China which are guarded and protected by their country's Coast Guard in the Indonesian Exclusive Economic Zone even with the Continental Shelf because they consider the area "Traditional Fishing Ground" they are based on Chinese historiography.

\section{The absence of an Exclusive Economic Zone boundary agreement}

The second problem is the absence of an exclusive economic zone agreement between Indonesia and several neighboring countries, especially Vietnam. So it formed "Undelimited Area" and resulted in illegal fishing carried out by KIA Vietnam which was escorted and protected by the country's Coast Guard. Vietnam considers the Indonesian Exclusive Economic Zone to be their territorial waters. The difference in understanding of the understanding of the regime of the Continental Shelf and the Exclusive Economic Zone is the reason why until now Vietnam has not made an agreement with Indonesia. Threats that occur due to 3 (three) problems are:

1. The occurrence of illegal fishing which resulted in huge losses for Indonesia because capture fisheries products were reduced and the fishermen did not dare to sail far to catch fish because of the presence of foreign KIA and Coast Guard.

2. Intervention from the Coast Guard of foreign countries in this case the State of Vietnam when law enforcement officers in the sea, especially ships of the Navy (KRI) and ships of the Ministry of Maritime Affairs and Fisheries (KKP) arrest KIA Vietnam which implements illegal fishing in Natuna waters can increase escalation Harmonious diplomatic relations between Indonesia and Vietnam and conflicts at the operational level in the field between Indonesian government vessels (KRI, KKP, Bakamla) and Vietnam government ships (Coast Guard), as well as other impacts, namely the inconvenience of oil and gas investors in the Natuna Block and Indonesian Fish Ships (KII) that catch fish in the North Natuna Sea. 
3. Illegal activities carried out by foreign warships that fly aircraft and operate landing craft or Landing Craft Vehicle Person (LCVP). These activities violated the United Nations Convention on the Law of the Sea (UNCLOS) in 1982 which based on UNCLOS 1982, foreign warships carrying out cross-country shipping or "Innocent Passage" had to sail continuously without stopping and without doing other activities.

The Nine-dash line problem in the South China Sea and involving several ASEAN countries, especially the Philippines, is currently growing. China officially rejected the decision issued by PCA, China continued to carry out the construction of artificial islands in the Spratly Islands. This is proven by the completion of the existing supporting infrastructure, such as docks and airstrips that can accommodate aircraft on artificial islands as a result of the China reclamation project in the Spratly Islands. Then China has managed to land its plane at Fiery Cross Reef.

This fact shows that China's seriousness in mastering the area included in the Nine-dash line claim. China continues to try to improve their military capabilities by increasing budget allocations to modernize their military capabilities and strength.

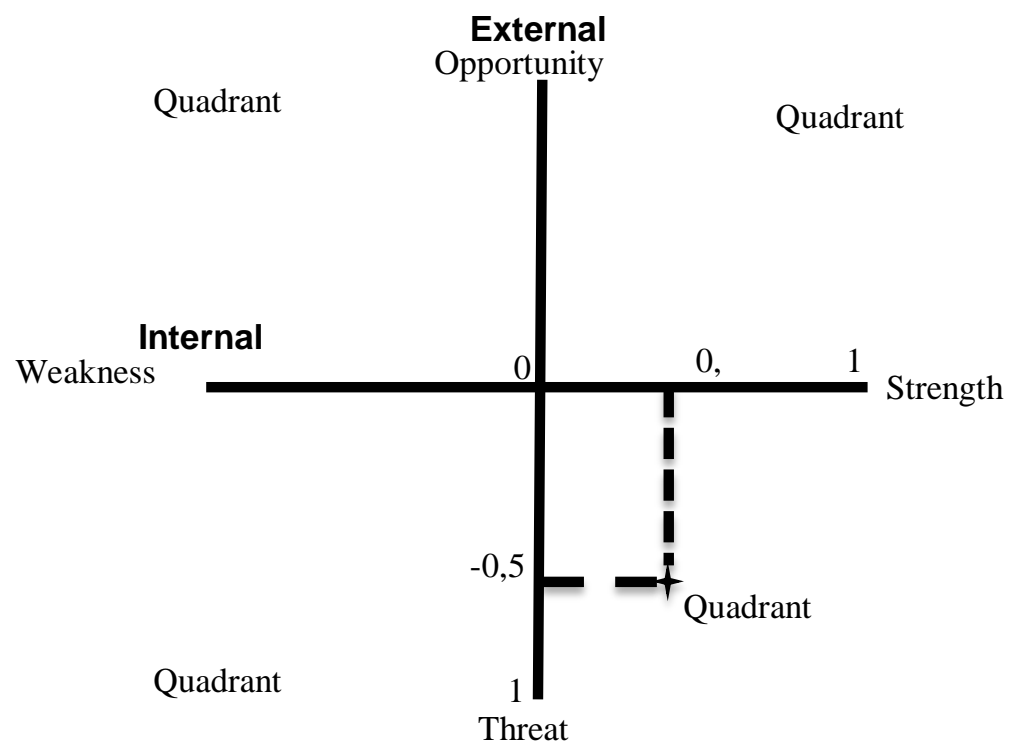

Figure 1:-SWOT Quadrant Table

In the quadrant strategy above, it shown that ST strategy is the best SWOT analysis results in this study. Furthermore, ST concepts and strategies can be formulated to optimize the management of strength factors and opportunities to overcome weaknesses and threats so that maritime resilience strengthening in Natuna Regency can be achieved. The ST Strategy is that the existing defense potential in the Regency of Nusauna must be able to be used to overcome all external threats, especially foreign activities in fishing theft (IUU) fishing in jurisdictional waters.

\section{Current Maritime Security Policy in Natuna Regency: -}

Natuna Regency Regional Regulation Number 8 of 2011 concerning the Regional Long-Term Development Plan for 2005-2025 (Regional Gazette of Natuna Regency in 2011 Number 8. Additional Regional Gazette of Natuna Regency in 2011 Number 8) explains that in the framework of integrating regional development planning into the national development system, all Regional Governments, both provincial and district / city, must prepare regional development planning documents consisting of the Regional Long Term Development Plan (RPJP), Regional Spatial Planning (RTRW) and Regional Medium Term Development Plan (RPJM). The Regional Government prepares Regional Government Work Plans (RKPD) each year which are preceded by Regional Development Planning Consultations (Musrenbang).

For further explanation, Natuna Regency's long-term development vision for the period 2005-2025 is "Becoming a Natuna MAS (Prosperous, Fair and Prosperous)", and then interpreted in the following terms: 
1. Prosperous is the realization of a society state that is fulfilled with all birth and inner needs evenly in all regions, strata and groups of society, supported by superior and high competitiveness, high-level, professional and forward-looking human resources.

2. Fair is the realization of a state of society that is free from fear and worry, free from disturbances and undermining that threatens physical and spiritual safety because of a sense of justice in the order of life. Justice is also manifested in the distribution of development throughout the region and all the potential and livelihoods of the people of Natuna Regency.

3. Prosperity is the realization of the condition of an advanced society and fulfilled all of its life needs as measured by improving quality from various aspects of life. Welfare is achieved through a balance between body and spirit as well as birth and mind. In the context of development, prosperity which will be realized is the creation of economic conditions that provide the level of living feasibility of the people of Natuna Regency with the fulfillment of basic community services, at least education and health services.

The Natuna Regency development policy direction compiled in the Regional RPJP is adjusted to the National RPJP period. While the periodization of the RPJMD cannot follow the periodization of the National RPJM because the election of the Regional Head is not held in conjunction with the election of the President. Thus the implementation of the Natuna Regency Regional RPJP for 2005-2025 is divided into the stages of development planning in the period of the 5 (five) annual RPJMD, as outlined in:

1. Regional Phase RPJM (2006-2011);

2. Phase II Regional RPJM (2011-2016);

3. Phase III Regional RPJM (2016-2021); and

4. Regional RPJM Phase IV (Year 2021-2025), where this period still has 1 (one) year left, on 2026.

Based on the explanation of key informants representing the Natuna Regency Government and stakeholders who support the management of oil and gas resource potential, it is known that the current policy direction in Natuna Regency has shown the seriousness of the Natuna District Government to strengthen maritime resilience. This can be seen from the explanation given below:

1. A further coordination meeting was held on the arrangement of the Spatial and Fisheries sector in Natuna Waters which was held on 9 April 2019 at the Ministry of Maritime Affairs Office which was attended by the Ministry / Institution (KL) and from the Navy. The meeting was chaired by the Coordinating Minister for Maritime Affairs and he directed that Natuna be built massively by synergizing between Defense and Security, Fisheries and Tourism. In the 3rd follow-up meeting, input material was collected from Natuna Regency as well as from KL and looked for bona fide Planning consultants to compile planning documents.

2. The Natuna District Government has the support of the Central Government and stakeholders regarding the plan to accelerate the development of 5 (five) pillars, as follows:

1. Acceleration of development in the field of defense and security, has been carried out and the existence of the Ranai airport, the Navy's dock in the Lampa Strait, several Navy posts.

2. The acceleration of development in the field of fisheries and maritime affairs has been carried out with the existence of an Integrated Fishery Center Center in the Lampa Strait built by the Ministry of Maritime Affairs and Fisheries.

3. Acceleration of development in the tourism sector, plans to manage local potential in Natuna but have not yet been implemented.

4. Acceleration of development in the oil and gas sector, plans to manage the potential of oil and gas in the Bay of Buton but have not yet been implemented.

5. Acceleration of development in the field of the environment, has been running after Natuna was designated as a National Geopark area which aims for conservation, education and the economy of the community. In addition, the Ministry of Foreign Affairs and the Ministry of Maritime Affairs are trying to encourage the National Geopark to become a UNESCO Global Geopark.

Stakeholders strive to jointly synergize starting from planning in accelerating development and infrastructure in accordance with their respective authorities. Then the private sector has not been much involved because there are still not many investors entering Natuna. While the community, community leaders and Scholars, youth and all parties strongly supported the development of maritime resilience in Natuna Regency through socialization by both the Natuna District Government and the socialization of the Navy itself. 
The current policy has not yet been fully felt by the private sector, in this case local entrepreneurs engaged in fisheries and also the people of Natuna Regency, who mostly work as fishermen.

The policies that have been compiled and implemented by the Natuna Regency Government to strengthen maritime resilience, one of which is to develop the fisheries and marine sector, which has not yet been felt by local entrepreneurs and people who work as fishermen. Until now, several policies that have been felt are as follows.

1. Development of Integrated Marine and Fisheries Centers (SKPT) as an integrated marine and fisheries business center from regional to upstream to downstream. So that the fish caught by the fishermen will be easily marketed.

2. Infrastructure assistance in the form of fishing vessels measuring $5 \mathrm{GT}$ and $10 \mathrm{GT}$.

3. The District Government has collaborated with the bank to collaborate with fishermen in capital.

However, until now, the policy that has been implemented by the Natuna Regency Government has not yet been directly affected by local entrepreneurs and the community. The followings are the problems that are felt related to the existence of these policies:

1. The selling price of caught fish in SKPT is not in accordance with the estimates and expectations of fishermen, because it is not balanced between the operational costs of fishermen during the operation to the sea;

2. Aid for fishing vessel infrastructure provided by the Ministry of Maritime Affairs and Fisheries has not played a maximum role because the size is too small. So it is not suitable for use in the North Natuna Sea;

3. Difficulties in terms of capital are still felt by fishermen. Even one solution is to borrow money from their boss;

4. The current condition of infrastructure, dock facilities and infrastructure is still limited. So that it has not been able to accommodate a large number of fishermen; and

5. There is no adequate transportation of fish transportation, so the sales distribution has not been maximized. It is expected that sales can turn into export scale so that the price of selling fish can be more expensive.

\section{Factors that Support and Inhibit the Implementation of Maritime Resilience Policy in Natuna Regency: -}

Based on the explanation of the maritime resilience conditions that exist in Natuna Regency faced with problems faced by both the District Government, stakeholders, the private sector, the community and law enforcement officers at sea, it will discuss what constitutes the inhibiting and supporting factors maritime resilience policy to be implemented in the Natuna Regency at this time. The following are the factors that support the implementation of maritime security policies in Natuna Regency.

\section{Internal}

1. The potential of Natuna Regency is very large, starting from fisheries and marine, tourism, oil and gas and the environment. This is evidenced by the variety of species of fish found in Natuna waters, such as small Pelagic Fish, large Pelagic Fish, Coral Fish, Lobster and Squid. Based on the data obtained, the average growth rate of the potential of Coral Fish starting from 2011 - 2017 reached 27.6\%.

2. The majority of the people in Natuna Regency are fishermen. This brings convenience for the Natuna Regency Government to optimize the potential of existing fisheries and marine resources because it does not need to start from zero exploration of fisheries and marine potential.

\section{External}

1. The Central Government's plan to develop Natuna Regency on a large scale in accordance with the results of a follow-up coordination meeting on the arrangement of the Spatial and Fisheries Sector in Natuna Waters which stated that Natuna was built massively by synergizing Defense and Security, Fisheries and Tourism. The meeting was chaired by the Coordinating Minister for Maritime Affairs at the Ministry of Maritime Affairs Office which was attended by the KL and from the Navy.

2. There is support from related stakeholders from the Oil and Gas sector in the form of Corporate Social Responsibility (CSR) programs. The program is a form of cooperation between SKK Oil and gas and Medco E \& P Natuna and Premier Oil Natuna Sea BV for the city of Natuna Regency. The concept of development carried out is child-friendly and healthy infrastructure, namely playgrounds for children and sports for adults. In addition, carried out the construction of the delivery of the people in Tanjung Pala Village, Pulau Laut District and the provision of radio communication equipment support for monitoring fishermen in Natuna Waters. 
Whereas the factors that hinder the implementation of maritime resilience policies in Natuna Regency are as follows:

\section{Internal}

1. The condition of infrastructure, facilities and infrastructure in Natuna Regency is inadequate. This is evident from the condition of the existing dock / port, the number of PELNIs that operate is still small, the support of fishing vessels size 5 GT and 10 GT cannot support and the Integrated Marine and Fisheries Center (SKPT) which is expected to support fishermen's welfare meeting their expectations because the fish caught are sold cheaply.

2. The synergy between the Natuna Regency Government and the private sector, the community and law enforcement officials is still lacking. This is evident from the policy that was made and implemented, it has not been able to optimize the potential that exists in Natuna Regency. Maybe the current policy has had a positive impact on the private sector and local entrepreneurs, but the fishermen still don't feel it. It can be said that the implementation of existing policies is still not comprehensive and touches all circles. Poor communication can be a factor, so that the aspirations of fishermen who act as the spearhead of the exploration of fisheries and marine potential have not been conveyed.

3. Limited ability of human resources to manage existing potential. Based on the facts, the highest educational facilities available in Natuna Regency are SMA / MA and SMK. Whereas in order to optimize the existing potential, experts who really understand the ins and outs and characteristics of the environment and ecosystems in Natuna are needed. this cannot be achieved if the Natuna District Government cannot improve and improve the quality of education for the sons and daughters of the Natuna region.

\section{External}

1. Illegal fishing activities that occur in the Natuna Sea.

2. Interventions from foreign country Coast Guards when law enforcement officers in the Indonesian sea will arrest KIA.

3. Illegal activities carried out by foreign warships when carrying out "Innocent Passage"

4. China's refusal of the arbitration decision was later realized in the form of building a military base in the Spratly island could potentially expand China's military power there. Thus giving rise to the potential loss of natural resources because China really seriously enforces the Nine-dash line claim in the South China Sea.

Based on the factors that support and inhibit it, it can be concluded that, Natuna already has enormous potential, such as fisheries and maritime affairs, tourism, oil and gas and the environment. This is supported by the majority of the human resources of the fishermen and the plan of the Central Government to carry out massive development in Natuna in an integrated manner. However, the existence of inhibiting factors can influence the process of policy implementation implemented in order to strengthen maritime resilience. So what is needed now is the existence of new concepts and strategies to be able to optimize the existing potential and overcome the problems faced in order to strengthen maritime resilience in Natuna.

\section{The Right Model and Strategy for Strengthening Maritime Resilience in Natuna Regency: -}

The final part of the discussion of the results of this study is to find appropriate and integrative models and strategies to strengthen maritime resilience in Natuna Regency. The existing maritime resilience conditions in Natuna Regency indicate a lack of existing building, facilities and infrastructure, but it is clearly seen that the potential is very large. This must continue to be managed and optimized. The presence of supporting and inhibiting factors is a description of whether the District Government's maritime resilience policies are currently well implemented. Based on the facts, the policy on strengthening maritime resilience has begun, but has not been able to touch all levels, especially the fishermen who have a very important role, such as the spearhead of exploration of fisheries and marine potential in Natuna Regency.

The geographical position of Natuna Regency, which is very strategic, with abundant natural resources, especially fisheries and oil and gas, has made the Natuna Islands and their waters a very valuable and inviting interest from regional countries to master them. It was then confronted with developing problems in the South China Sea due to the Nine-dash line claim that was unilaterally carried out by China and the agreement of the Exclusive Economic Zone boundary between Indonesia and Vietnam had not been agreed upon to become a major problem that must be resolved. Because the impact caused is very large and causes huge losses. Based on the data obtained, the potential growth rate of potential fish in Natuna has decreased. Recorded in 2016 the potential of fish in WPP 711 including 
the North Natuna Sea reached 1,143,340 tons, while in 2017 it decreased to 767,155 tons. This is predicted as a result of the high rate of illegal fishing.

As a nation that has a historical background as a maritime nation, Natuna Regency should be able to optimize the management of its existing potential, especially fisheries and marine and oil and gas. Then in the last few years tourism has become a potential that can be developed, in November 2018, the Indonesian Government officially designated Natuna as the National Geopark area. In the modern era like today, conventional models and strategies are considered to be less interesting because they use old, outdated methods. As a region that has unique characteristics with a wealth of potential, problems that are not easy to solve and classified access are still limited, interesting and innovative strategy models are needed.

Hybrid theory presents as an answer for developing innovative models and strategies. Charles Jenks in "Hybrid Language" (1978) and "New Paradigm Architecture" (1991) say that hybrid is a method for creating things with old patterns (history) but with new materials and techniques. Hybrid concepts have characteristics which are carried out through the stages of quotation, element manipulation and unification or merging.

1. Planning is too vague, without clear objectives that can be used to monitor and evaluate project success or failure;

2. Management responsibility is unclear; and

3. Evaluation is often a process of hostility because there is no mutual agreement on what the project really wants to achieve.

Armed with the background of the Indonesian people who at that time was known as "Nusantara" was a very large maritime country especially in the golden age of the Kingdom of Sriwijaya and Majapahit became a concept that was on the traditional side. Then the presence of the Nawa Cita strategy and Indonesia's Vision as the World Maritime Axis are red lines that connect history in the past and try to be rebuilt (reconstruction) as a concept of modern maritime resilience. By using hybrid theory, the concept of an archipelago maritime country will be combined with the concept of a modern maritime country so that a new model or concept can emerge which is called "Hybrid Maritime Resilience Model or Concept". This model or concept tries to combine the positive side of the government concept used by the Kingdom of Sriwjaya and Majapahit so that it can make the archipelago a great maritime country of its time with the Nawa Cita and Pillar Strategy in the World Maritime Axis that can strengthen maritime resilience conditions.

\section{Archipelago of Srivijaya and Majapahit era (Traditional maritime resilience concept):-}

Singgih Tri Sulistiyono (2016) in the "Maritime Paradigm in Building Indonesia: Learning from History" published in the History Sheet of Volume 12, Number 2, pages 81-108 explains that Indonesia has a geographical strategic position along the international maritime trade route (silk road) between 2 (two) superpowers at that time, namely India and China. One of the keys to Srivijaya's success in becoming a great maritime country in its time was a policy and attitude that was responsive to its geostrategic environment where Sriwijaya was not a passive object to its strategic position. The people in the era of the Srivijaya kingdom not only waited for foreign traders to come to sell and buy goods, but in subsequent developments they also became decisive players as accomplished sailors and traders.

Anastasia Wiwik (2010) in the "Natuna Region Toponymy" published by the Center for Preservation of Traditional History and Values explains that during the era of the Srivijaya Kingdom, Natuna became a shelter from the fierce raging storm of the South China Sea. The Natuna Islands at that time became a shelter as well as a place to fill clean water and other supplies to continue the voyage. The ships passed the SNatuna Islands because of trade activities with China, Siam and Campa. It can be said that at that time, the Natuna Islands had the conditions of infrastructure, the existing facilities and infrastructure were good because they were able to accommodate the needs of clean water and other supplies.

The Majapahit Kingdom controlled its territory through expansionary habits that put forward persuasive ways. If this method is not successful, military force will be used (Irawan Djoko Nugroho, 2011). This custom gave birth to the customary law of territorial control, if an area had been subdued under the Majapahit kingdom, then the Majapahit Government generally did not interfere with the internal affairs of the area. The Majapahit Kingdom only required the area to (Megandaru W. Kawuryan, 2006):

1. Give tribute; 
2. Send envoys at certain times as a sign of subjugation under the control of the Majapahit kingdom and in making decisions in accordance with the wishes of the Majapahit Government for its territory; and

3. Use Majapahit's power as an influence on the area for regions that far from the center of power of the Majapahit kingdom.

Majapahit Kingdom developed not only from the basis of agricultural economics but also the development of shipping and trade activities as a maritime country. Sea trade is not only carried out between one region and another in the archipelago, but has penetrated into a wider and international territory. Pigeud (1960) argues that imported goods have been known by the Majapahit community to the interior such as textiles from India and glassware and precious stones from China. Chao Ju-kua testified that Chinese commodities purchased by Javanese traders included gold, silver, silk, varnish and porcelain.

The trade fleet owned by the Majapahit kingdom was able to sail and compete in the waters of the archipelago and even to navigate the Indian Ocean and South China Sea to trade with China. The Majapahit royal navy was able to control the territory and traffic around the Malacca Strait which was the gateway to international trade in the region. At the same time, residents of Majapahit are able to produce and sell trade commodities needed by the international market. On the one hand, traders and seafarers can make a profit, while the government can draw taxes and various income related to trade activities and shipowners have the opportunity to develop their investments into larger businesses. In order for all activities to run smoothly, the Majapahit kingdom made structural adjustments in the bureaucracy and the domestic market which could be a catalyst between local markets and international markets (Hall, 1985). This shows that the mechanism as a maritime state involves all the potential that exists in society as a system, where economic activities are not only intended for the interests of exports but also for their own interests and domestic needs.

Nawa Cita and the World Maritime Axis (The concept of modern maritime security):-

Mochdar Soleman and Mohammad Noer (2017) in "Nawacita As Jokowi's Special Strategy for October 2014 to 20 October 2015" published in the Journal of Political Studies and Development Problems, volume 13, number 1 explained that after being named as a presidential candidate in the 2014 presidential election, Jokowi in its vision and mission document it describes Trisakti Bung Karno's ideas into Nawa Cita as a general strategy of his government.

Nawa Cita is literally nine goals that will be a reference for the performance of the Jokowi-JK government. Of the 9 (nine) programs carried out by President Joko Widodo, which are closely related to the plan to strengthen maritime resilience in Natuna Regency are the first, second and third programs, there are:

1. Presenting the state to protect all nations and providing security to all citizens, through free and active foreign policy, trusted national security and the development of integrated state defense Tri Matra based on national interests and strengthening identity as a maritime country.

2. Making the government not absent by building clean, effective, democratic and trustworthy governance, by giving priority to efforts to restore public trust in democratic institutions by continuing democratic consolidation through reform of party systems, elections and representative institutions.

3. Building Indonesia from the periphery by strengthening regions and villages within the framework of a unitary state.kingdom

4. Refuse weak countries by implementing system reform and law enforcement that are corruption-free, dignified, and trusted.

5. Improving the quality of Indonesian human life through improving the quality of education and training with the "Smart Indonesia" program and improving the welfare of the community with the "Indonesia Employment" and "Prosperous Indonesia" programs by encouraging 9 hectares of land reform and land ownership programs. Cheap subsidized series or flats and social security for the people in 2019.

6. Increasing people's productivity and competitiveness in the international market so that the Indonesian people can advance and rise with other Asian nations.

7. Realizing economic independence by mobilizing strategic sectors of the domestic economy.

8. Revolutionizing the nation's character through a policy of restructuring the national education curriculum by prioritizing aspects of citizenship education, which places proportionally the aspects of education, such as teaching the history of nation formation, patriotism values and the love of the country, the spirit of defending the country and character in Indonesian education curriculum. 
9. Strengthening diversity and strengthening Indonesia's social restoration through policies to strengthen diversity education and create spaces for dialogue between citizens.

The first, second and third programs were used as the initial steps of the Central Government to carry out massive development in the Natuna Islands in the border region. Starting from the development of national defense based on national interests and strengthening identity as a maritime country, then the development of clean, effective, democratic and reliable governance is a form of applying the principles of good governance.

The three programs were then strengthened by the vision of the World Maritime Axis. Ali Maksum (2015) in his article entitled "Maritime Axis and Jokowi's Foreign Politics", published in the Andalas Journal of International Studies, volume 4, number 1, explained that the idea of a world maritime axis or "Global Maritime Axis" was President Joko's big idea Widodo (Jokowi) who has been campaigned since the 2014 Presidential Election (Pilpres) campaign. The idea came amid various national problems such as corruption, budget leakage, injustice and so on. The idea of a maritime axis became the great hope of the Indonesian people to return to their identity as seafaring nations. In addition, it was stated that the idea of a maritime axis was nothing but to improve connectivity between very weak islands due to poor facilities and infrastructure. This is a maritime axis main agenda that aims to connect thousands of kilometers of coastline, especially by adding port facilities. (Vibhanshu Shekhar and Joseph Chinyong Liow, 2014).

The concept of the World Maritime Axis is set forth in Presidential Regulation No. 2 of 2015 concerning the 2015-2019 National Medium-Term Development Plan (RPJMN). Indonesia as the World Maritime Axis is supported by 5 (five) main pillars, namely:

1. Reconstruction of Indonesian maritime culture.

2. Commitment to maintain and manage marine resources by focusing on building sea food sovereignty through the development of the fishing industry by placing fishermen as the main pillars.

3. Commitment to encourage infrastructure development and maritime connectivity by building sea tolls, seaports, logistics and shipping industries, as well as maritime tourism.

4. Maritime diplomacy that invites all Indonesian partners to work together on the marine sector.

5. Building the power of maritime defense.

Maritime policy has had consequences for the Indonesian government. If you want to truly realize its vision, there are several things that must be implemented by the government:

1. Modernization of the port system to conform to international standards;

2. Construction of a new dock to support the Sea Toll program so as to accelerate the connection of all Indonesian territories especially the leading islands of the NKRI;

3. Increasing the intensity of trade because this is in line with the increase in shipping intensity so that it is expected to grow the economy; and

4. Development and strengthening of TNI bases in the border region and the foremost islands to realize the TNI posture that can maintain the sustainability of the maritime axis policy. In addition, the presence of the TNI as an element of national defense will certainly be a deterrence effect for the potential threats. At the national level, the presence of the TNI will increase the nationalism and patriotism of the people in the border region and the leading islands of the Republic of Indonesia.

The second pillar in the World Maritime Axis which shows the government's commitment to maintain and manage marine resources by focusing on building sea food sovereignty through the development of the fishing industry by placing fishermen as the main pillars.

One tangible form of the Nawa Cita program and the World Maritime Axis is the "Sea Toll Program". Dodi Agustina (2016) in the "Realization of the Construction of Sea Tolls as Inter-Island Connectivity in Indonesia in the Face of the World Economic Globalization Era", Faculty of Economics, Semarang State University, explained that the breakthrough was the development of the concept of sea toll through the elaboration of sea transport route planning, sea transportation subsidies, revitalization of people's shipping and the development of industrial commodities based on regional commodities are important things to be realized. Through this connectivity, it is hoped that it will make distribution of goods, services and production factors easier, because it is hoped that through this infrastructure Indonesia can benefit from maritime modalities to accelerate growth in various regions in Indonesia and build maritime competitiveness. 
Lesmana Rian Andhika (2018) explained that there are many ways of hybrid theory so that it can be formulated in different ways, combining several related theories and maybe the theory will work together or independently will build a reference. So that most people will use causal factor and descriptive factor information in making, assessing references and becoming a domain for building hybrid concepts (Genone and Lombrozo, 2012).

Ningsar and Deddy Erdiono (2012) explained in "Comparison of the Concept of Hybrid Architecture and Symbiosis Architecture" that the hybrid concept is a mixture or descent from 2 (two) things that are contradictory. Hybrid itself consists of crossing, mixing and merging. The definition of hybrids began to develop in the architectural world defined by architectural theorists with the following meanings:

1. Charles Jenks in "Hybrid Language" (1978) and "New Paradigm Archtecture" (1991) say that hybrid or hybrid is a method for creating things with old patterns (history) but with new materials and techniques.

2. Kisho Kurowa (1991) in "Intercultural Architecture (The Philosophy of Symbiosis)" says that hybrids mean combining or mixing the best elements from different cultures, both between contemporary cultures with the past (diachronic) or between contemporary cultures (synchronous). Thus hybrids accept the use of multiple references across cultures and history.

The first step is Eclectic or Quotation, which is to trace and select the treasury of forms as well as architectural elements from the past that are considered potential to be reappointed.

Table 1:-Potential past elements to be reappointed

\begin{tabular}{|l|l|}
\hline NO & \multicolumn{1}{|c|}{ THE CONCEPT OF THE MARITIME COUNTRY (TRADITIONAL) } \\
\hline 1. & $\begin{array}{l}\text { The royal leader (Raja and Mahapatih) has a vision, mission, strong and firm character and leadership to } \\
\text { build and advance the kingdom and territory }\end{array}$ \\
\hline 2. & $\begin{array}{l}\text { Having the strength of a strong naval fleet so that it is able to expand into the regions of the archipelago, } \\
\text { regional and international areas and maintain stability in this matter is to use naval power to protect areas } \\
\text { under its control }\end{array}$ \\
\hline 3. & $\begin{array}{l}\text { Able to control trade centers and surrounding shipping traffic with military force and control pirates not to } \\
\text { disrupt trade routes }\end{array}$ \\
\hline 4. & $\begin{array}{l}\text { Can develop politics, diplomacy and the military as a strategy to overcome the potential threat of attacks } \\
\text { from other countries by sending royal envoys to other countries or kingdoms }\end{array}$ \\
\hline 5. & Make a policy that increases income through taxes paid when carrying out trade activities in his territory \\
\hline 6. & $\begin{array}{l}\text { Synergizing the tradition of river commerce and agrarian traditions with the maritime potential that has been } \\
\text { mastered }\end{array}$ \\
\hline 7. & $\begin{array}{l}\text { Reaffirming the attitude to face influences from foreign parties by punishing royal officials and kings under } \\
\text { his authority who disobey or violate the orders of the king or the ruling leader }\end{array}$ \\
\hline 8. & $\begin{array}{l}\text { The holder of power milestones often carries out visits to his territory to interact directly while listening to } \\
\text { petitions coming from his people and controlling his territory }\end{array}$ \\
\hline 9. & $\begin{array}{l}\text { The mechanism as a maritime state is shown by involving all the potential that exists in the community for } \\
\text { the development of the kingdom and the welfare of the people; }\end{array}$ \\
\hline 10. & Economic activity is not only intended as an export interest but also for the needs of the people \\
\hline Source: Processed da and analysis, 2019 a
\end{tabular}

Source: Processed data and analysis, 2019

These 10 (ten) elements are the best potential that can be taken from the concept of traditional maritime resilience. Furthermore, you must find elements from the past (the concept of modern maritime resilience) that have potential and can be used. These elements are taken from the existing Nawa Cita Program and the World Maritime Axis Pillar, then whichever has the potential to be able to improve maritime resilience in Natuna Regency.

Tabel 2:-Potential past elements to be reappointed

\begin{tabular}{|c|l|}
\hline NO & \multicolumn{1}{|c|}{ THE CONCEPT OF THE MARITIME STATE (MODERN) } \\
\hline 1. & $\begin{array}{l}\text { Presenting the concept as a state that protects the whole nation through the development of the TNI as a } \\
\text { means of national defense to achieve national security and strengthen themselves as a form of maritime } \\
\text { defense. }\end{array}$ \\
\hline 2. & $\begin{array}{l}\text { Building a clean, effective, democratic government to restore public trust in the role of the Central, } \\
\text { Provincial and Regional Governments. }\end{array}$ \\
\hline
\end{tabular}




\begin{tabular}{|c|l|}
\hline 3. & $\begin{array}{l}\text { Develop villages and suburbs by developing maritime infrastructure and connectivity with all Central, } \\
\text { Provincial and Regional Government partners }\end{array}$ \\
\hline 4. & $\begin{array}{l}\text { Maintaining and managing marine resources with a focus on building marine food sovereignty through the } \\
\text { development of the fishing industry by placing fishermen as the main pillar as a form of rebuilding maritime } \\
\text { culture. }\end{array}$ \\
\hline
\end{tabular}

Source: Data Proceed and analysis, 2019

Both the concept of maritime resilience, both traditional and modern, are known to be potential elements and can be presented back to the new strategy model or concept that will be offered.

The second step is implementing Manipulation and Modification. The resulting elements of the Quotation are manipulated or modified in ways that can shift, change and / or distort existing meanings. This can be done with several techniques:

1. Reduction or simplification;

2. Repetition;

3. Distortion of forms;

4. Disorientation;

5. Proportion; and

6. Dislocation.

After the manipulation and modification process has been carried out, the concept of modern maritime resilience is now in accordance with the conditions and needs of Natuna Regency. The third step is merging (combination or unification). This step is the last step in the hybrid theory concept to combine or unite several elements that have been manipulated or modified into a predetermined design. By using hybrid theory, a new model or concept has been found namely "Hybrid Maritime Resilience Model or Concept" as a result of the merger of the Traditional Maritime Resilience Concept and the Modern Maritime Resilience Concept. Then in the process of merging (combination or unification), a specific strategy formula can be used that can be used to improve maritime resilience in Natuna Regency, which named "PASTI MAJU" Strategy.

\section{$P$ (Defense and Security)}

Having strong defense and security forces by increasing the quality and quantity of the main and reserve components, which named the Indonesian Armed Forces and related law enforcement agencies in Natuna Regency, supported by the conditions of adequate facilities, infrastructure and infrastructure both sea, air and land.

\section{A (Anticipation)}

Having the ability to anticipate actions by using reserve and supporting components in supporting the main components to protect Natuna Regency from various threats and disturbances that exist.

\section{S (Economic, Social and Political Stability)}

Optimizing the ability to build the economy and create a stable social and political life by providing opportunities for all elements of society both the private sector and the community to actively participate and contribute and cooperate with local governments and other relevant officials in the development process and social life in order to improve stability economic, social and political.

\section{T (Tough and Characteristic)}

Have a strong mental struggle to work hard to get a better life and have maritime characters according to Natuna's geographic constellation in the form of an archipelago and have a nationalist spirit to build and develop the potential that exists in the region in order to realize the Natuna Regency's MAS vision and mission (Evenly, Fair and Prosperous).

\section{I (Integrity and Synergy)}

Having a strong spirit of integrity and a good and synergic cooperation relationship between the local government, the private sector, religious leaders, youth leaders and the general public as well as law enforcement officials in managing various potentials and in overcoming various problems so as to create dynamic and harmonious conditions in community life and in an effort to accelerate development in Natuna Regency. 


\section{M (Management)}

Applying a management system correctly in managing various potentials that are owned from the planning, implementation, supervision and evaluation phases as well as overcoming various problems and obstacles that exist by implementing the principles of good, accountable, transparent governance, involving community participation and legal certainty. and the same legal treatment to all levels of society.

\section{A (Fair and Even)}

The management of the potential must be carried out optimally by applying the principles of good governance, accountability, transparency and legal certainty so that the development results can be felt and enjoyed by the entire Natuna community fairly and evenly.

\section{J (Honest)}

Honesty is the main key to success in various aspects of life. Honesty in the implementation of governance and in the development process starting from the planning, implementation, supervision and evaluation stages can prevent manipulation, corruption and budget leakage and can build trust between government administrators, the community and law enforcement officials. So that honesty values must be continuously instilled and applied in everyday life in the family, community, education and government environment.

\section{U (Urgency and Continuity)}

The constraction that carried out must be planned properly based on priority scale or urgency so that no mistakes can occur that can cause the development process to collapse or be abandoned due to miss-planning, namely by prioritizing productive development both micro and macro sectors that can open opportunities for community employment and development facilities, infrastructure and facilities that can support the movement of the economy. In addition, the development program carried out must be continuous or continuous based on the grand design planning that has been made, although there are changes in officials in the government but development can be carried out according to the plans that have been prepared.

"PASTI MAJU" strategy formulation compiled by the author is a form of thinking comprehensively considering that in the context of the Natuna Regency national perspective has been designated as an area that has several functions and strategic potential so that demands a different management pattern from other districts. The "PASTI MAJU" strategy formulation can be used as a formulation of a new policy to optimize the management of existing potentials in Natuna Regency.

The next step is the authority of the Natuna Regency Government, if you want to use the "PASTI MAJU"strategy as a new policy formulation, then the Natuna Regency Government must provide "Legitimation" or endorsement of "PASTI MAJU"as a Regency Government policy by building cooperation that promises to achieve the objectives of the program design SURE FORWARD program. After the legal force has been established, programs in the PASTI FORWARD strategy can be implemented as "Policies". But this should not stop here, because after the implementation of existing programs, an "Evaluation" must be carried out to assess the performance and impact of the program. This will influence the decision whether the programs will be continued or need to be adjusted back to the needs in order to optimize the development and management of existing potentials in Natuna Regency. Policy formulation in practice will involve a variety of actors, both state and non-state actors or so-called official policy makers and non-government participants (Anderson in Wahab, 2005). Official policy makers are those who have the legal authority to be involved in the formulation of public policies, with a composition consisting of the Legislature, Executive, Administrative Agency and the Court.

The concept and strategy of "PASTI MAJU" have been prepared taking into account the interests of National Defense in development planning. The concept of National Resilience in development is an implementation of the Archipelago Insight and National Resilience in planning, implementing, controlling and evaluating development so that the following principles can be found in development planning:

1. Able to answer all challenges, threats, obstacles and disturbances as well as opportunities and constraints, both coming from within and outside the country (including the impact of the globalization era);

2. Able to strengthen national unity and integrity as well as environmental sustainability in the Republic of Indonesia

3. Able to be at each stage of development, departing from the real conditions (real) of increasing National Resilience which is expected in the future; and 
4. Able to integrate development planning vertically and horizontally.

Where development is carried out comprehensively and integrally in all aspects of national life by taking into account the values of Pancasila, the 1945 Constitution and Archipelago Insight. So that there is a vertical development plan, that is, development planning should be able to integrate the interests and aspirations of the people with direction from the top (bottom up and top down planning) and horizontal development planning, namely development planning that is able to integrate between sectors and the development sector by determining the development goals that must be achieved by all related sectors by determining the department / institution as the main responsible. The presence of the concept of National Resilience in development has a very strong role in the success of formulating the "PASTI MAJU" strategy and programs that can be implemented by the Natuna Regency Government to strengthen its Maritime Resilience.

\section{Conclusions And Suggestions:-}

\section{Conclusions: -}

The condition of maritime resilience in Natuna Regency is currently still low due to several factors, such as follows:

1. Management of maritime potential in Natuna Regency, especially the marine and fisheries, oil and gas, tourism and environment sectors, so that the level of welfare and education and health services to the Natuna community is still low.

2. The condition of facilities, infrastructure and infrastructure for ports and sea transportation in Natuna Regency is still minimal so that it has not been able to support trade, economy, goods distribution and community activities optimally as well as the need for fast, safe and comfortable marine transportation equipment for Natuna community and Natuna outside.

3. The condition of facilities, infrastructure and facilities for land transportation infrastructure in Natuna is still inadequate so that it has not been optimal in supporting the distribution of goods from natural, industrial and trade products quickly and safely to remote rural areas.

4. The condition of facilities, infrastructure and facilities for air transportation infrastructure in Natuna is still inadequate so that it has not been optimal in providing access, number and alternative flight routes to and from Natuna;

5. The quality of human resources in Natuna is still low due to the low level of education and lack of ability to manage the potential of natural resources owned as a result of the lack of facilities, infrastructure and facilities and education and training, both formal and non-formal and not yet optimal. Education and health services to the Natuna community.

6. The condition of internet communication and network facilities is still limited, thus hampering the process of digitalization in the fields of government, economy, industry and trade and slowing down access to communication and electronic transactions;

7. The ability of defense and security in Natuna Regency is still weak and has not been able to prevent early sovereignty and legal violations by foreign parties in the Natuna Sea, especially the actions of illegal fishing carried out by Vietnamese fishermen on ZEEI and the Indonesian continental shelf ;

8. Collaboration and synergy between the Natuna Regency Government and the private sector, the community and law enforcement officials need to be improved in order to be able to optimize the management of various potentials owned by Natuna Regency for the welfare of the community fairly and evenly, and be able to overcome various problems, weaknesses, obstacles, challenges, interference and threats.

The final synthesis of the SWOT and AHP analysis results are as follows:

1. The ST Strategy is the best strategy with a weight value of 0.393 , namely the existing defense potential in Natuna Regency must be able to be used to overcome all external threats, especially foreign activities in fishing theft (IUU) Fishing in waters of Indonesia's National jurisdiction.

2. The development of defense and security forces in Natuna Regency must be increased in order to support the development plans in Natuna Regency that are jointly prepared by the central government, provincial government and local government.

3. Development of priority scale infrastructure is needed that can be used to overcome external threats and the rise of illegal, Unreported and Unregulated (IUU) fishing.

4. Inadequate condition of infrastructure, facilities and infrastructure can be prioritized in the development plans that will be jointly implemented by the Central Government, Provincial Governments and Regional Governments. 
The Maritime Resilience Policy in Natuna Regency is currently implementing accelerated development in 5 (five) potential pillars of Natuna Regency, are:

1. Acceleration of development in the field of defense and security, has been running and the existence of the Ranai airport, the Navy's dock in the Lampa Strait, several Navy posts.

2. The acceleration of development in the field of fisheries and maritime affairs has been carried out with the existence of the Integrated Fishery Center Center in the Lampa Strait built by the Ministry of Maritime Affairs and Fisheries.

3. Acceleration of development in the tourism sector, plans to manage local potential in Natuna but have not yet been implemented.

4. Acceleration of development in the oil and gas sector, plans to manage the potential of oil and gas in the Bay of Buton but have not yet been implemented.

5. Acceleration of development in the field of the environment, has been running after Natuna was designated as a National Geopark area which aims for the conservation, education and economy of the community. In addition, the Ministry of Foreign Affairs and the Ministry of Maritime Affairs are trying to encourage the National Geopark to become a UNESCO Global Geopark.

The factors that support and hinder the implementation of maritime resilience policies in Natuna Regency are as follows.

\section{Supporting factors \\ Internal}

1. The potential of Natuna Regency is very large, starting from fisheries and marine, tourism, oil and gas and the environment.

2. The majority of the people in Natuna Regency are fishermen.

\section{External}

1. Plans for the Central Government to develop Natuna Regency on a large scale according to the results of a follow-up coordination meeting on the arrangement of the Spatial and Fisheries sectors in the Natuna Waters

2. There is support from related stakeholders from the Oil and Gas sector in the form of Corporate Social Responsibility (CSR) programs.

\section{Inhibiting factors \\ Internal}

1. The condition of infrastructure, facilities and facilities in Natuna Regency is inadequate

2. The synergy between the Natuna Regency Government and the private sector, the community and law enforcement officials is still lacking

3. Limited capacity of human resources to manage existing potential

\section{External}

1. The high illegal fishing activities that occur in the Natuna Sea.

2. Interventions from foreign country Coast Guards when law enforcement officers in the Indonesian sea will arrest KIA.

3. Illegal activities carried out by foreign warships at "Innocent Passage".

4. China's rejection of the arbitration decision, then realized in the form of building a military base in the Spratly Islands that could potentially expand China's military power there. Thus giving rise to the potential loss of natural resources because China really seriously enforces the Nine-dash line claim in the South China Sea.

The right and integrative concept and strategy to strengthen maritime resilience in Natuna Regency is "Hybrid Maritime Resilience" with a "PASTI MAJU" strategy. The concept and strategy using the hybrid theory is an amalgamation of the Traditional Maritime Resilience Concept (The Age of Glory of the Kingdom of Sriwijaya and Majapahit) and the Modern Maritime Resilience Concept (Nawacita Program and World Maritime Axis Pillar) using the processes in hybrid theory. The "PASTI MAJU" strategy and the programs there in are supported by the concept of National Resilience in development so that it is expected to be able to:

1. Optimizing the various potentials of Natuna Regency as a strength factor and being able to take advantage of existing opportunities and be able to face all challenges, threats, obstacles and disturbances both coming from within and outside the country (including the impact of the globalization era); 
2. Strengthening the unity and integrity as well as the environmental preservation of the people of Natuna Regency within the Republic of Indonesia.

3. Able to integrate development planning vertically and horizontally so as to increase maritime resilience in Natuna Regency.

\section{Suggestion: -}

1. The Natuna Regency Government needs to optimize cooperation with the central government in this case the relevant ministries and institutions, the private sector and the community for the improvement and improvement of facilities, infrastructure and facilities for the sea, air and land to support the economic, trade, industry and tourism sectors. In addition, the Natuna Regency Government must also inventory potentials that can be managed and developed and analyze problems, weaknesses, shortcomings, obstacles, challenges, threats and disturbances so that they can be prevented and overcome so that the accelerated process of development can be carried out properly.

2. The Natuna Regency Government needs to create a new policy that has a concept of development with priority scale so that it can encourage the acceleration of development and management of natural resources and the various potentials that exist in Natuna, both in the form of regulatory policies and the ease of the community in opening a business (home industry) and obtaining work. For example, implementing cooperation or MOU with the Coordinating Ministry of Maritime Affairs for the development of the maritime sector that is integrated with other fields, with national banks for ease of business capital lending, with the Ministry of transportation for the improvement and improvement of facilities, infrastructure and Sarpras for sea, air and sea transportation and land, with the Ministry of Maritime Affairs and Fisheries to provide education and training to fishermen and coastal communities considering the majority of the Natuna people are fishermen, supporting modern boat infrastructure and fishing equipment capable of operating up to ZEEI, building cool storage and fisheries processing industry centers, with the Ministry of Defense, the Indonesian National Armed Forces, POLRI and other relevant agencies to strengthen aspects of defense, security and handling illegal activities such as illegal fishing by foreign fishermen, as well as implementing Collaboration with other ministries / institutions in relevant fields. By making policies in enhancing cooperation it is hoped that it can accelerate development and strengthen maritime resilience in Natuna.

3. The Natuna Regency Government must be able to manage and empower the factors that support it optimally in order to overcome various factors that hamper the implementation of maritime resilience policies in Natuna Regency, so as to accelerate the strengthening of maritime resilience in Natuna.

4. The Natuna Regency Government can use the Hybrid Maritime Resilience concept with "PASTI MAJU" strategy as the formulation of a "new policy", and can implement its programs comprehensively to support the Natuna Regency development plan on a large scale by the Central Government so that the management of the Trigatra Aspect can be optimized in order to improve the condition of the Pancagatra Aspect in the context of strengthening Indonesia's Maritime and National Resilience in the Natuna region.

\section{Bibliography:-}

1. Agustina, Dodi, 2016. "Realisasi Pembangunan Tol Laut Sebagai Konektivitas Antar Pulau di Indonesia dalam Menghadapi Era Globalisasi Ekonomi Dunia". Fakultas Ekonomi, Universitas Negeri Semarang.

2. Charles, Jenkcs, 1978. "Hybrid Language".

$3 . \quad$, 1991. "New Paradigma Architecture".

4. Genone, J., dan Lombrozo, T., 2012. "Concept Possession, Experimental Semantics and Hybrid Theories of Reference”. Philisopical Psychology, 25 (5), 717-742. Doi:10.1080/09515089.2011.627538.

5. Hall, Kenneth R., 1985. "Maritime Trade and State Development in Early Southeast Asia". Honolulu: University of Hawaii Press.

6. Holling, C.S. 2001. Understanding the Complexity of Economic, Ecological and Social Systems. Ecosystems 4(5): $390-405$

7. Irawan Djoko Nugroho, 2011. "Majapahit Peradaban Maritim Ketika Nusantara Menjadi Pengendali Pelabuhan Dunia". Jakarta: Yayasan Suluh Nuswantara Bakti.

8. Kurowa, Kisho, 1991. "Intercultural Architecture (The Philosophy of Symbiosis)". New York: The American Institute of Architect Press 1735.

9. Maksum, Ali, 2015. "Poros Maritim dan Politik Luar Negeri Jokowi". Andalas Journal of International Studies. Volume 4, No. 1. ISSN 2301-8208.

10. Mashud dan Musta'in, 2005. "Metode penelitian sosial". Jakarta: Kencana. 
11. Megandaru, W. Kawuryan., 2006. "Tata Pemerintahan Negara Kertagama Keraton Majapahit”. Jakarta: Panji Pustaka.

12. Ningsar dan Erdiono, Deddy, 2012. "Komparasi Konsep Arsitektur Hibrid dan Arsitektur Simbiosis". Universitas Sam Ratulangi, Manado.

13. Peraturan Daerah Kabupaten Natuna Nomor 8 Tahun 2011 tentang Rencana Pembangunan Jangka Panjang Daerah tahun 2005-2025 (Lembaran Daerah Kabupaten Natuna Tahun 2011 Nomor 8. Tambahan Lembaran Daerah Kabupaten Natuna Tahun 2011 Nomor 8)

14. Pigeud, 1960-1963. "Java in the Fourteenth Century: A Study in Cultural History IV". The Hague.

15. Rian Andhika, Lesmana, 2018. "Inovasi Birokrasi: Perspektif Analisis Hybrid Teori”. Jurnal Borneo Administrator. Volume 14, No. 2. E-ISSN 2407-6767. P-ISSN 1858-0300.

16. Soleman, Mochdar dan Noer Mohammad, 2017. "Nawacita Sebagai Strategi Khusus Jokowi”. Jurnal Kajian Politik dan Masalah Pembangunan. Vol 13, No. 1.

17. Spradley, J.P., 1980. "The participation observation”. New York: Reinhart \& Winston.

18. Sulistiyono, Singgih Tri, 2016. "Paradigma Maritim dalam Membangun Indonesia: Belajar dari Sejarah". Lembaran Sejarah. Volume 12, number 2. Halaman 81-108. ISSN 1410-4962.

19. U.S. Department of Homeland Security Center of Excellence, 2016. "Integrating Maritime and Coastal Resilience". $7^{\text {th }}$ Annual Maritime Resilience Symposium

20. Wiwik, Anastasia, 2010. “Toponimi Daerah Natuna”. Balai Pelestarian Sejarah dan Nilai Tradisional. 